\title{
GDF-15 protects from macrophage accumulation in a mousemodel of advanced atherosclerosis
}

\author{
Michael R Preusch ${ }^{1}$, Matthias Baeuerle ${ }^{1}$ Claudia Albrecht ${ }^{1}$, Erwin Blessing ${ }^{1}$, Marc Bischof $^{2}$, Hugo A Katus ${ }^{1}$ \\ and Florian Bea ${ }^{1,3^{*}}$
}

\begin{abstract}
Background: The cytokine growth differentiation factor-15 (GDF-15), a member of the TGF beta superfamily, has recently been discovered to play an important role in cardiovascular diseases. It is mostly expressed in macrophages of atherosclerotic lesions, but its impact on advanced atherosclerosis is still unknown. This study was performed to evaluate the effects of GDF-15 in an established mouse model of advanced atherosclerosis.

Methods: Thirty-eight LDL receptor deficient mice received a lethal body radiation. Half of the group was transplanted with bone marrow of GDF-15 deficient mice. Nineteen mice were transplanted with bone marrow from wild-type controls. After 24 weeks on an atherogenic diet, animals were euthanized and sections of the aortic sinus were prepared. Lesion size and lesion composition, as well as macrophage content,were evaluated.

Results: While demonstrating no difference in lesion size, LDL-receptor knockout mice transplanted with bone marrow from GDF-15 deficient mice showed enhanced macrophage accumulation and features of atherosclerotic plaque destabilization, such as thinning of fibrous caps. Immunostaining against intercellular adhesion molecule-1 further revealed an increased expression in mice receiving GDF-15-deficient bone marrow.
\end{abstract}

Conclusions: This is the first study that demonstrates a protective role of GDF-15 in advanced atherosclerosis and macrophage accumulation, possibly due to the reduced expression of adhesion molecules.

\section{Background}

Cytokines are known to play a key role in the development and progression of atherosclerosis [1]. Among these, members of the transforming growth factor- $\beta$ (TGF- $\beta$ ) superfamily have been shown to contribute to the development of vascular inflammation $[2,3]$. Recently, growth differentiation factor-15 (GDF-15), a member of the TGF- $\beta$ family, has been identified to participate in cardiovascular pathology. GDF-15, also known as macrophage inhibitory cytokine-1, prostate-derived factor or non-steroidal anti-inflammatory drug-activated gene-1, is a $12-\mathrm{kDa}$ secreted protein (and a $25-\mathrm{kDa}$ disulfide-linked dimer) which is, besides in placenta and prostate, not expressed under basal conditions. It can be induced by inflammation, injury, and malignancy $[4,5]$.

\footnotetext{
* Correspondence: florian.bea@klf-net.de

1 Department of Internal Medicine, University of Heidelberg, Im Neuenheimer Feld 410, 69120 Heidelberg, Germany

${ }^{3}$ Freudenstadt Hospital, Karl-von-Hahn-Str. 120, 72250 Freudenstadt, Germany

Full list of author information is available at the end of the article
}

Furthermore, GDF-15 is involved in apoptosis and cardiac hypertrophy, and can be induced by biomechanical stretch [6-9]. In addition, several clinical studies have investigated its role in cardiovascular diseases. GDF-15 is described as a novel biomarker with a high impact on risk stratification and prognostic value in myocardial infarction, chronic heart failure, and pulmonary embolism [10-13]. The mechanisms through which GDF-15 acts, however, seem complex and are still unclear. In atherosclerotic lesion development, most experimental studies have demonstrated the anti-atherogenic properties of TGF- $\beta[14,15]$; however, these have not been defined for the different members of the TGF- $\beta$ superfamily $[2,16]$. Recently, a study by de Jager et al.demonstrated an anti-atherosclerotic effect of GDF15 deficiency in low-density lipoprotein (LDL) $\mathrm{r}^{-/-}$mice 4 and 12 weeks after initiation of a hyperlipidemic diet [17]. However, it is not known how GDF-15 acts in the advanced stages of atherosclerosis that we often find in human disease. In the present study, we tested whether GDF-15 alters lesion size and lesion composition in an advanced stage of atherosclerosis.

\section{Biomed Central}




\section{Methods}

Animals and bone marrow transplantation

Eight-week-old female LDL-receptor ${ }^{-/-}$mice $\left(\mathrm{LDLr}^{-/-}\right.$, background C57/BL/6; Jackson Laboratory, Bar Harbor, USA; $n=38$ ) received lethal body irradiation at a dose of 9 Gy. Half of the group $(n=19)$ was transplanted with bone marrow of mice $(n=5)$ with a GDF-15 knock-out [18]. Nineteen $\mathrm{LDLr}^{-/-}$mice were used as controls, which were transplanted with bone marrow of wild-type mice (C57/BL/6CR). After transplantation, mice were fed a high fat western-type diet (Altromin, Lage/ Germany; Nr. 11320010: 0.15\% cholesterol) for 24 weeks. Animals were kept within the animal care facility of the University of Heidelberg. The investigation conforms to the Guide for the Care and Use of Laboratory Animals published by the US National Institutes of Health (NIH Publication No. 85-23, revised 1996). The housing and care and procedures in the study were performed in accordance with the guidelines and regulations composed by the Animal Care Committee of the University of Heidelberg and approved by the Regierungspraesidium Karlsruhe.

\section{Animal sacrifice and preparation of tissues}

After 24 weeks on a high cholesterol Western-type diet, mice were heavily sedated (Avertin, Aldrich, Milwaukee, USA), blood was collected from the inferior vena cava, and the animals were sacrificed by exsanguination (fasted $3 \mathrm{~h}$ prior to sacrifice). The animals were perfused with $10 \mathrm{~mL}$ phosphate-buffered saline, followed by a perfusion with $4 \%$ buffered formalin via the left ventricle. The entire heart from each animal was dissected out, embedded in paraffin, and the aortic sinus was serially sectioned $(5 \mu \mathrm{m})$. Every fifth section was stained with a modified Movat's pentachrome stain [19].

\section{Assessment of chimerism}

The reconstitution of the transplanted bone marrow was determined by PCR on liver and spleen tissue.

\section{Determination of plasma lipid concentration}

Total serum cholesterol, high-density lipoprotein (HDL), LDL cholesterol, and triglycerides were determined enzymatically in heparinized plasma.

\section{Evaluation of lesion size and lesion composition}

Two investigators who were blinded to the study protocol determined the cross-sectional area of the lesion in each section by using computer-assisted morphometry (Image Pro, Media Cybernetics, Silver Spring, USA); this is reported as mean plaque area per animal (data expressed in $\mu \mathrm{m}^{2}$ ). We further evaluated each section for characteristic features of plaque morphology/composition: thickness of the fibrous cap (presented as $\mu \mathrm{m}$ ), size of the necrotic core (a large necrotic core was defined as occupying more than $50 \%$ of the plaque's volume and was measured by computer). Calcification was determined using von Kossa staining [20].

\section{Immunohistochemistry}

Detection of monocytes/macrophages was performed using monoclonal goat anti-mouse antibody (anti-Mac-2, Accurate, NY, USA) and detection of ICAM-1 by using a polyclonal antibody (Santa Cruz Biotech, CA, USA). Sections were incubated with the biotinylated secondary antibody, rinsed three times with PBS, and incubated for 10 minutes with streptavidin at room temperature. AECchromogen substrate (Invitrogen, Karlsruhe, Germany) was used for visualization. The extent of positive staining within the lesions was determined using computerassisted morphometry and is presented as ratio stained area/total lesion area (Image Pro, Media Cybernetics, Silver Spring, USA).

\section{Statistical analysis}

All data were expressed as mean \pm SEM. Differences between means in plasma lipid profiles were determined with the two-tailed unpaired student's $t$-test. For analysis of plaque morphometry and areas of positive staining, groups were compared using the two-tailed MannWhitney $U$ test. For evaluation of plaque morphology, groups were compared using the $\chi^{2}$ test. A $p$ value $<0.05$ was considered statistically significant.

\section{Results \\ Effect of bone marrow transplantation}

Polymerase chain reaction analysis of the bone marrow demonstrated a complete conversion of the original $\mathrm{LDLr}^{-/-}$genotype to the donors' type, indicating that the bone marrow population had been reconstituted (data

Table 1 Distribution of body weight, total serum cholesterol, LDL cholesterol, HDL cholesterol, and serum triglycerides of recipients of GDF-15 $15^{-/}$bone marrow (GDF-15 $15^{-/}$) and wild-type controls (GDF-15 $5^{+/+}$) ( $p$ was non-significant)

\begin{tabular}{|c|c|c|c|c|c|c|}
\hline & Body weight (g) & $\begin{array}{c}\text { Total cholesterol } \\
\text { (mg/dL) }\end{array}$ & $\begin{array}{l}\text { LDL cholesterol } \\
(\mathrm{mg} / \mathrm{dL})\end{array}$ & $\begin{array}{l}\text { HDL cholesterol } \\
\text { (mg/dL) }\end{array}$ & $\begin{array}{c}\text { Triglycerides } \\
\text { (mg/dL) }\end{array}$ & Lesion size $\left(\mu \mathrm{m}^{2}\right)$ \\
\hline GDF-15 ${ }^{+/+}(W T)(n=15)$ & $28 \pm 1$ & $351 \pm 28$ & $293 \pm 26$ & $25 \pm 2$ & $159 \pm 20$ & $246,566 \pm 14,788^{+}$ \\
\hline GDF-15 ${ }^{-/-}(K O)(n=17)$ & $29 \pm 1$ & $364 \pm 15$ & $309 \pm 14$ & $28 \pm 3$ & $134 \pm 5$ & $203,079 \pm 17,898^{\dagger}$ \\
\hline
\end{tabular}

Quantitative evaluation of lesion size within the aortic root also showed no significant difference between the groups $(p=0.08) ;$ Mean $\pm \mathrm{SEM}{ }^{\dagger} p=0.08$.

WT: wild-type (recipients of bone marrow from C57/Black 6 control mice); KO: knock-out (recipients of bone marrow from GDF-15 negative mice). 


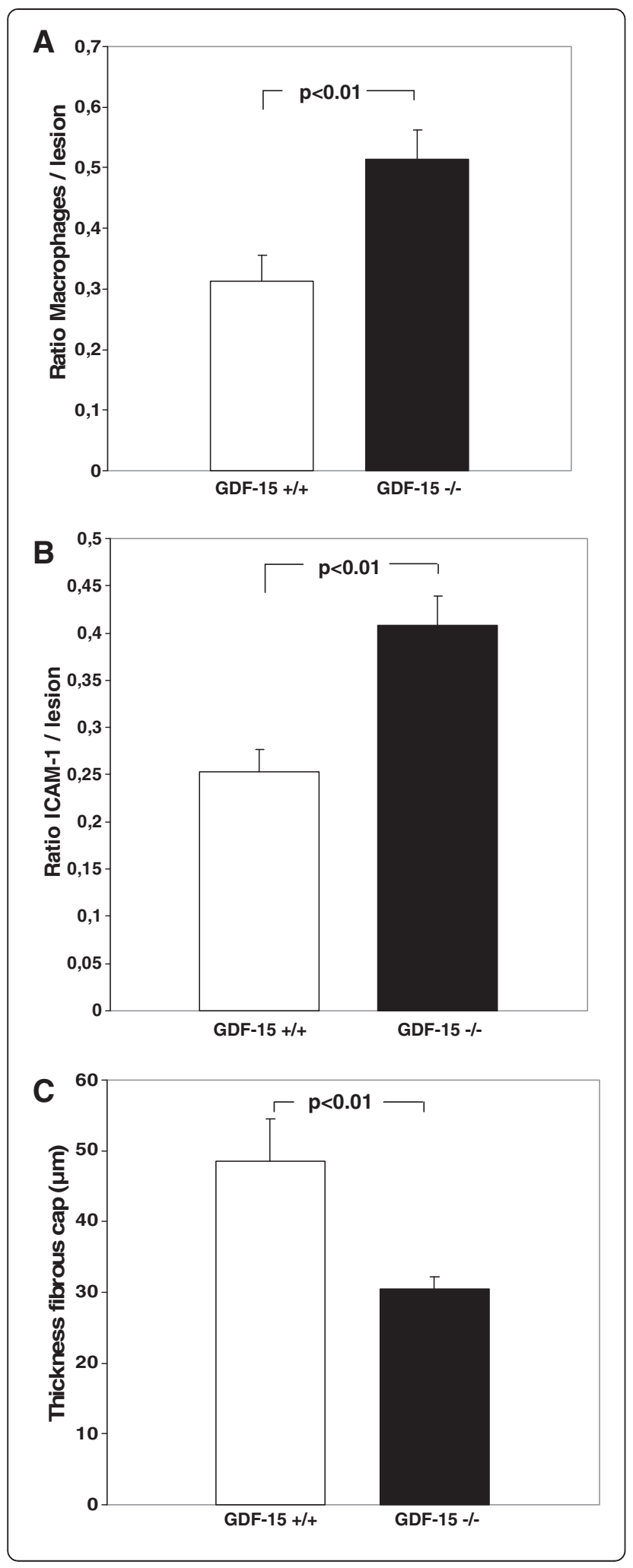

Figure 1 Enhanced macrophage accumulation and ICAM-1 expression within the atherosclerotic lesions of mice transplanted with bone marrow from GDF-15 ${ }^{-/-}$donors.

(A) Video-microscopic evaluation of positive staining for macrophages (Mac-2-staining) showed significant enhanced macrophage accumulation within the atherosclerotic lesions of $\mathrm{LDLr}^{-/-}$mice transplanted with bone marrow from GDF-15 $15^{-1-}$ mice in comparison to wild-type controls $(p<0.01)$. Data are presented as ratio positive macrophage staining/lesion; Mean \pm SEM. (B) Video-microscopic evaluation of positive staining for ICAM-1 demonstrated a significant enhanced expression within atherosclerotic lesions of $\mathrm{LDLr}^{-/}$mice transplanted with bone marrow from GDF-15 $15^{-1}$ mice compared to wild-type controls $(p<0.01)$. Data are presented as ratio positive ICAM-1 staining/lesion; Mean \pm SEM. (C) Atherosclerotic lesions of $\mathrm{LDL}^{-/-}$mice transplanted with bone marrow from GDF-15 $15^{-/}$donors $(p<0.01)$ showed a significantly thinner fibrous cap than controls. Data are presented as $\mu \mathrm{m}$ thickness; Mean \pm SEM.

not shown). There were no differences in body weight and mortality between the groups.

\section{Effect on plasma lipid level and body weight}

There were no significant differences in total cholesterol, LDL, HDL, and triglycerides between mice that received GDF- $15^{-1-}$ bone marrow and controls. Furthermore, there was no difference in body weight (Table 1).

\section{Mean lesion area}

After 24 weeks on the western type diet, the extent of atherosclerotic lesion development in the aortic sinus was evaluated. We could not detect any significant difference in lesion size $\left(\mathrm{GDF}-15^{+/+} 246.566 \pm 14.788 \mu \mathrm{m}^{2}\right.$ versus $\mathrm{GDF}-15^{-/-} 203.079 \pm 17.898 \mu \mathrm{m}^{2}, p=0.08$; Table 1 ).

\section{Enhanced macrophage content in GDF-15 deficient mice}

After 24 weeks on the western-type diet, we were able to demonstrate macrophage rich lesions and enhanced foam cell formation evaluated by macrophage staining in both groups. Mice transplanted with bone marrow of GDF- $15^{-1-}$ donors showed enhanced macrophage accumulation within atherosclerotic lesions $(0.51$ versus 0.31 ; $p<0.01$; Figures $1 \mathrm{~A}$ and $2 \mathrm{~A}$ ).

Mice transplanted with GDF-15 deficient bone marrow showed enhanced expression of intercellular adhesion molecule-1 (ICAM-1)

ICAM-1 staining was enhanced in atherosclerotic lesions of chimeric mice ( 0.41 versus 0.25 in wild-type controls, $p<0.01$; Figures $1 \mathrm{~B}$ and $2 \mathrm{~B})$.

\section{Features of lesion composition}

Video-microscopic evaluation of features of lesiondestabilization showed significantly more thinning of the fibrous cap in $\mathrm{LDLr}^{-/-}$mice transplanted with bone marrow from GDF- $15^{-/-}$mice than in controls $(48.5 \mu \mathrm{m}$ 


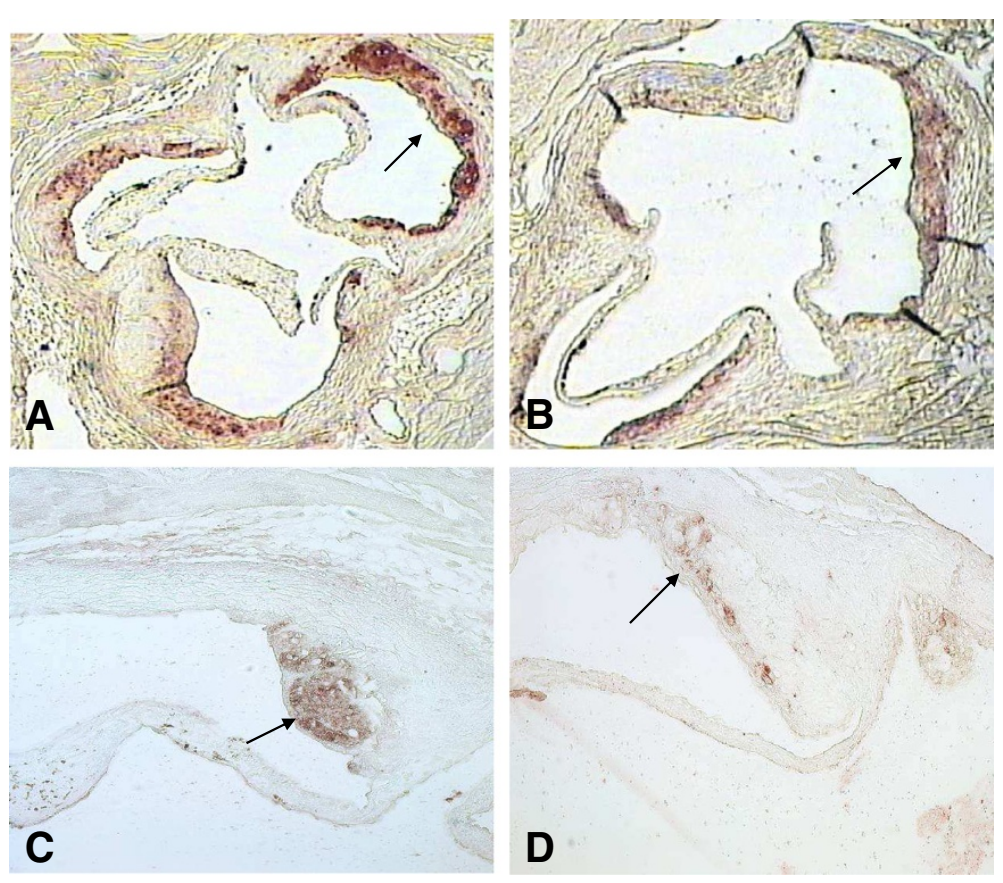

Figure 2 Macrophage staining of the aortic root of a $\mathrm{LDLr}^{-/}$mouse, transplanted with bone marrow from a GDF-15 ${ }^{-1}$ donor (A) demonstrated an enhanced macrophage accumulation (arrows) within the atherosclerotic lesion compared to a control animal (B). Staining for ICAM-1 furthermore showed an increased expression (arrows) in animals transplanted with GDF-15 deficient bone marrow (C) in contrast to controls (D). Pictures demonstrate a colocalization of macrophages and ICAM-1.

versus $30.5 \mu \mathrm{m}, p<0.01$; Figure $1 \mathrm{C})$. We could not detect any difference in size of the necrotic core or calcification within the lesions (data not shown).

\section{Discussion}

Recent studies have hypothesized a crucial role of the cytokine GDF-15 in cardiovascular diseases. While clinical investigations demonstrate GDF-15 as a parameter for risk stratification in myocardial infarction and heart failure, experimental studies show a cardio-protective effect in ischemia and reperfusion [7,10-13];furthermore, GDF-15 is correlated with systemic inflammation [21]. These data suggest an involvement of GDF-15 in the initiation and progression of atherosclerosis. Recently, de Jager et al. demonstrated an anti-atherosclerotic effect of GDF-15 deficiency in a mouse model of atherosclerosis [17]. The authors used $\mathrm{LDLr}^{-/-}$mice transplanted with GDF-15-deficient bone marrow. In this study, GDF-15 deficiency resulted in a reduction of early atherosclerotic lesion size after 4 weeks on a high cholesterol westerntype diet. After 12 weeks, no differences in lesion size could be detected. Using mice following 24 weeks on a western-type diet, we focused on more advanced and complex lesions to model late-stage disease. It is known that lesions in mice become quite complex with increased duration of feeding [22]. We could not detect any differences in lesion size, but in contrast to the findings of de Jager et al., our data demonstrated a proinflammatory plaque phenotype in mice transplanted with bone marrow from GDF-15 $15^{-/}$donors with enhanced macrophage accumulation [17]. In the present study macrophages were identified by using a Mac-2 antibody, which is an appropriate staining used in many $\mathrm{LDLr}^{-/-}$mouse studies. We cannot exclude that staining for other macrophage markers will identify different subpopulations of macrophages with different results. The increase seen in our study was accompanied by enhanced expression of ICAM-1 within lesions.

Monocyte/macrophage recruitment is dependent on adhesion molecules [23]. ICAM-1 is mostly expressed by endothelial cells but also in macrophages within atherosclerotic lesions and it is supposed to be involved in foam cell transformation of monocytes and therefore contributes to changes in lesion vulnerability [24,25].

Our data also confirm a correlation between enhanced macrophage content and signs of the vulnerable plaque determined by the thickness of fibrous caps. This is in line with autopsy findings of ruptured plaques in human [26]. Macrophages excrete an excess of matrix-degrading enzymes and macrophage-rich lesions, and therefore most likely undergo thinning of the fibrous caps and subsequent enhanced vulnerability followed by plaque rupture $[27,28]$. However, our findings of an association between GDF-15 deficiency and reduced plaque stability 
are in contrast to the findings of de Jager et al., where a decreased necrotic core formation in GDF- $15^{-/-}$chimera is reported [17]. It is known that at one point in atherosclerotic lesion development, changes in plaque composition but not progression of size,are dominating. The increase in macrophages and the subsequent increase in inner-plaque inflammation finally results in a reduction of plaque stability. Other than the effect on fibrous caps, we could not detect any differences in other features of lesion destabilization, which might also be due to the duration of the study and the animal model since it is known that differences in necrotic core and hemorrhage are more common in brachiocephalic arteries in ppoE $^{-/-}$ mice [29].

There are several limitations to our study. Investigating atherosclerotic lesions in $\mathrm{LDLr}^{-/-}$mice is mostly done in the aortic root, which is not a typical lesion location. It is known as a model of early stages in atherosclerosis and does not show much progress in late-stage disease [30,31]. We did not focus on the onset of atherosclerotic changes within the vascular wall such as lipid accumulation in younger mice. Evaluation of fibrous caps was performed morphometrically as in many $\mathrm{LDLr}^{-/-}$ mouse studies. Given the amount of tissue obtained, we were not able to stain for other parameters such as the differences in collagen content. Further, we do not know if bone-marrow transplantation has an effect on other cytokines, the immunosystem, or metabolism, which is an important factor in atherosclerosis. Recently, it has been shown that GDF-15 is a key regulator in anorexia, and weight and fat loss [32]. However, lipid levels and body weight in our study were equally distributed. We could not detect any further change in lethality after transplantation.

\section{Conclusions}

In conclusion, this is the first study evaluating the effects of GDF-15 in advanced stages of atherosclerosis. We were able to demonstrate a GDF-15-dependent inhibition of macrophage adhesion and accumulation in an atherosclerotic $\mathrm{LDLr}^{-1-}$ mouse model. This effect may contribute to changes in lesion vulnerability such as thinning of fibrous caps and potential plaque rupture.

\section{Abbreviations \\ GDF-15: Growth differentiation factor-15; HDL: High-density lipoprotein; LDL: Low-density lipoprotein; TGF- $\beta$ : Transforming growth factor- $\beta$.}

\section{Competing interest}

All authors declare that they have no competing interests.

\section{Authors' contribution}

$\mathrm{MB}$ and $\mathrm{CA}$ carried out the immunostaining, PCR and lesion analyses. MBi performed the body irradiation. MRP, MB, EB, and FB, participated in the design of the study and performed the statistical analysis. MP, HAK, and FB conceived the study and participated in its design and coordination, and helped to draft the manuscript. All authors read and approved the final manuscript.

\section{Acknowledgements}

We would like to thank Annette Buttler, Heike Ziebart, and Alec Selby for expert technical assistance.

\section{Author details}

'Department of Internal Medicine, University of Heidelberg, Im Neuenheimer Feld 410, 69120 Heidelberg, Germany. ${ }^{2}$ Department of Radiooncology, University of Heidelberg, Im Neuenheimer Feld 400, 69120 Heidelberg, Germany. ${ }^{3}$ Freudenstadt Hospital, Karl-von-Hahn-Str. 120, 72250 Freudenstadt, Germany.

Received: 28 February 2013 Accepted: 29 May 2013

Published: 24 June 2013

\section{References}

1. Girn HR, Orsi NM, Homer-Vanniasinkam S: An overview of cytokine interactions in atherosclerosis and implications for peripheral arterial disease. Vasc Med 2007, 12:299-309.

2. Robertson AK, Rudling M, Zhou X, Gorelik L, Flavell RA, Hansson GK: Disruption of TGF-beta signalling in T cells accelerates atherosclerosis. J Clin Invest 2003, 112:1342-1350.

3. Topper JN: TGF-beta in the cardiovascular system: molecular mechanisms of a context-specific growth factor. Trends Cardiovasc Med 2000, 10:132-137.

4. Bootcov MR, Bauskin AR, Valenzuela SM, Moore AG, Bansal M, He XY, Zhang HP, Donnellan M, Mahler S, Pryor K, Walsh BJ, Nicholson RC, Fairlie WD, Por SB, Robbins JM, Breit SN: MIC-1, a novel macrophage inhibitory cytokine, is a divergent member of the TGF-beta superfamily. Proc Natl Acad Sci U S A 1997, 94:11514-11519.

5. Welsh JB, Sapinoso LM, Kern SG, Brown DA, Liu T, Bauskin AR, Ward RL, Hawkins NJ, Quinn DI, Russell PJ, Sutherland RL, Breit SN, Moskaluk CA, Frierson HF Jr, Hampton GM: Large-scale delineation of secreted protein biomarkers overexpressed in cancer tissue and serum. Proc Natl Acad SC U S A 2003, 100:3410-3415.

6. Schlittenhardt D, Schober A, Strelau J, Bonaterra GA, Schmiedt W, Unsicker K, Metz J, Kinscherf R: Involvement of growth differentiation factor-15 /macrophage inhibitory cytokine-1 (GDF-15/MIC-1) in oxLDL-induced apoptosis of human macrophages in vitro and in arteriosclerotic lesions. Cell Tissue Res 2004, 318:325-333.

7. Kempf T, Eden M, Strelau J, Naguib M, Willenbockel C, Tongers J, Heineke J, Kotlarz D, Xu J, Molkentin JD, Niessen HW, Drexler H, Wollert KC: The transforming growth factor-beta superfamily member growthdifferentiation factor- 15 protects the heart from ischemia/reperfusion injury. Circ Res 2006, 98:351-360.

8. Xu J, Kimball TR, Lorenz JN, Brown DA, Bauskin AR, Klevitsky R, Hewett TE, Breit SN, Molkentin JD: GDF15/MIC-1 functions as a protective and antihypertrophic factor released from the myocardium in association with SMAD protein activation. Circ Res 2006, 98:342-350.

9. Frank D, Kuhn C, Brors B, Hanselmann C, Lüdde M, Katus HA, Frey N: Gene expression pattern in biomechanically stretched cardiomyocytes: evidence for a stretch-specific gene program. Hypertension 2008, 51:309-318.

10. Wollert KC, Kempf T, Peter T, Olofsson S, James S, Johnston N, Lindahl B, Horn-Wichmann R, Brabant G, Simoons ML, Armstrong PW, Califf RM, Drexler $\mathrm{H}$, Wallentin $\mathrm{L}$ : Prognostic value of growth-differentiation factor15 in patients with non-ST-elevation acute coronary syndrome. Circulation 2007, 115:962-971.

11. Wollert KC, Kempf T, Lagerqvist B, Lindahl B, Olofsson S, Allhoff T, Peter T, Siegbahn A, Venge P, Drexler $H$, Wallentin L: Growth differentiation factor 15 for risk stratification and selection of an invasive treatment strategy in non ST-elevation acute coronary syndrome. Circulation 2007, 116:1540-1548.

12. Kempf T, Björklund $E_{,}$Olofsson S, Lindahl B, Allhoff T, Peter T, Tongers J, Wollert KC, Wallentin L: Growth-differentiation factor-15 improves risk stratification in ST-segment elevation myocardial infarction. Eur Heart J 2007, 28:2858-2865.

13. Kempf $\mathrm{T}$, von Haehling $\mathrm{S}$, Peter $\mathrm{T}$, Allhoff $\mathrm{T}$, Cicoira M, Doehner $\mathrm{W}$, Ponikowski P, Filippatos GS, Rozentryt P, Drexler H, Anker SD, Wollert KC: Prognostic utility of growth differentiation factor- 15 in patients with chronic heart failure. J Am Coll Cardiol 2007, 50:1054-1060. 
14. Mallat Z, Gojova A, Marchiol-Fournigault C, Esposito B, Kamaté C, Merval R, Fradelizi D, Tedgui A: Inhibition of transforming growth factor-beta signaling accelerates atherosclerosis and induces an unstable plaque phenotype in mice. Circ Res 2001, 89:930-934.

15. Lutgens E, Gijbels M, Smook M, Heeringa P, Gotwals P, Koteliansky VE, Daemen MJ: Transforming growth factor-beta mediates balance between inflammation and fibrosis during plaque progression. Arterioscler Thromb Vasc Biol 2002, 22:975-982.

16. Ago T, Sadoshima J: GDF15, a cardioprotective TGF-beta superfamily protein. Circ Res 2006, 98:294-297.

17. de Jager SC, Bermúdez B, Bot I, Koenen RR, Bot M, Kavelaars A, de Waard V, Heijnen CJ, Muriana FJ, Weber C, van Berkel TJ, Kuiper J, Lee SJ, Abia R, Biessen EA: Growth differentiation factor 15 deficiency protects against atherosclerosis by attenuating CCR2-mediated macrophage chemotaxis. J Exp Med 2011, 208:217-225.

18. Strelau J, Strzelczyk A, Rusu P, Bendner G, Wiese S, Diella F, Altick AL, von Bartheld CS, Klein R, Sendtner M, Unsicker K: Progressive postnatal motoneuron loss in mice lacking GDF-15. J Neurosci 2009, 29:13640-13648.

19. Movat $\mathrm{HZ}$ : Demonstration of all connective tissue elements in a single section; pentachrome stains. AMA Arch Pathol 1955, 60:289-295.

20. Puchtler H, Meloan SN: Demonstration of phosphates in calcium deposits: a modification of von Kossa's reaction. Histochemistry 1978, 56:177-185.

21. Skipworth RJ, Deans DA, Tan BH, Sangster K, Paterson-Brown DA, Hunter M, Breit SN, Ross JA, Fearon KC: Plasma MIC-1 correlates with systemic inflammation but is not an independent determinant of nutritional status or survival in oesophago-gastric cancer. Br I Cancer 2010, 102:665-672.

22. Reardon CA, Blachowicz L, Lukens J, Nissenbaum M, Getz GS: Genetic background selectively influences innominate artery atherosclerosis: immune system deficiency as a probe. Arterioscler Thromb Vasc Biol 2003, 23:1449-1454

23. Duplàa C, Couffinhal T, Labat L, Moreau C, Petit-Jean ME, Doutre MS, Lamazière JM, Bonnet J: Monocyte/macrophage recruitment and expression of endothelial adhesion proteins in human atherosclerotic lesions. Atherosclerosis 1996, 121:253-266.

24. Davies MJ, Gordon JL, Gearing AJ, Pigott R, Woolf N, Katz D, Kyriakopoulos A: The expression of the adhesion molecules ICAM-1, VCAM-1, PECAM, and E-selectin in human atherosclerosis. J Pathol 1993, 171:223-229.

25. Yang PY, Rui YC: Intercellular adhesion molecule-1 and vascular endothelial growth factor expression kinetics in macrophage-derived foam cells. Life Sci 2003, 74:471-480.

26. Burke AP, Farb A, Malcom GT, Liang YH, Smialek J, Virmani R: Coronary risk factors and plaque morphology in men with coronary disease who died suddenly. N Engl J Med 1997, 336:1276-1282.

27. Loree HM, Tobias BJ, Gibson L, Kamm RD, Small DM, Lee RT: Mechanical properties of model atherosclerotic lesion lipid pools. Arterioscler Thromb 1994, 14:230-234.

28. Sukhova GK, Schönbeck U, Rabkin E, Schoen FJ, Poole AR, Billinghurst RC, Libby P: Evidence for increased collagenolysis by interstitial collagenases1 and -3 in vulnerable human atheromatous plaques. Circulation 1999, 99:2503.

29. Jackson CL, Bennett MR, Biessen EA, Johnson JL, Krams R: Assessment of unstable atherosclerosis in mice. Arterioscler Thromb Vasc Biol 2007, 27:714-720

30. Sjöland H, Eitzman DT, Gordon D, Westrick R, Nabel EG, Ginsburg D: Atherosclerosis progression in LDL receptor-deficient and apolipoprotein $\mathrm{E}$-deficient mice is independent of genetic alterations in plasminogen activator inhibitor-1. Arterioscler Thromb Vasc Biol 2000, 20:846-852.

31. Breslow JL: Mouse models of atherosclerosis. Science 1996, 272:685-688.

32. Johnen $H$, Lin S, Kuffner T, Brown DA, Tsai WW, Bauskin AR, Wu L, Pankhurst G, Jiang L, Junankar S, Hunter M, Fairlie WD, Lee NJ, Enriquez RF, Baldock PA, Corey E, Apple FS, Murakami MM, Lin EJ, Wang C, During MJ, Sainsbury A, Herzog H, Breit SN: Tumor-induced anorexia and weight loss are mediated by the TGF-beta superfamily cytokine MIC-1. Nat Med 2007, 13:1333-1340.

doi:10.1186/2047-783X-18-19

Cite this article as: Preusch et al: GDF-15 protects from macrophage accumulation in a mousemodel of advanced atherosclerosis. European Journal of Medical Research 2013 18:19.

\section{Submit your next manuscript to BioMed Central and take full advantage of:}

- Convenient online submission

- Thorough peer review

- No space constraints or color figure charges

- Immediate publication on acceptance

- Inclusion in PubMed, CAS, Scopus and Google Scholar

- Research which is freely available for redistribution 